\title{
LIPID CONTENT OF HUMAN COSTAL AND ARTICULAR CARTILAGE
}

\author{
BY \\ R. A. STOCKWELL \\ Department of Anatomy, St. Thomas's Hospital Medical School, London
}

Sacerdotti (1900) established that fat is a normal and constant constituent of the chondrocyte. Extracellular lipid in normal cartilage was described by Putschar (1931). Many histological investigations of the lipid content of cartilage have since been made, culminating in the ultrastructural observations of Zbinden (1953), Collins, Ghadially, and Meachim (1965), and Ghadially, Meachim, and Collins (1965). Few quantitative studies exist. Sacerdotti (1900) carried out a small number of analyses on rabbit ear cartilage, and Hass (1943) studied an age-series of specimens of human costal cartilage. No conclusive results were obtained with respect to age changes. In the present quantitative study, a comparison is made of the age changes in the lipid content of post mortem human costal and articular cartilage.

\section{Material and Methods}

Cartilage was used from 45 human post mortem cases with no history of joint disease. Ages at death ranged from 2 days to 89 years. The fourth costal cartilage was removed, the perichondrium stripped off, and tissue free of macroscopic degenerative changes taken for lipid extraction. Normal articular cartilage was taken from the medial femoral condyle. The complete thickness of the cartilage (superficial to the calcified zone) was pared off the bone from the middle region of the condyle.

(a) Lipid Extraction.-The solvent used was 2:1 chloroform/methanol. Tissue was sectioned into slices less than $0.5 \mathrm{~mm}$. thick and placed in a small volume of solvent for $\mathbf{2}$ hours. It was then extracted in a Soxhlet apparatus for 12 hours (repeated extractions using this time period did not result in a significant increase in the amount of lipid extracted). The solvent plus extract was then washed with $0.05 \mathrm{~N} \mathrm{NaCl}$ by the method of Folch, Lees, and Sloane-Stanley (1957). Repeated evaporation to dryness at $60^{\circ} \mathrm{C}$. and solution in chloroform-methanol was used to free lipid complexes of protein, the final soluble residue being taken up in chloroform. The weight of chloroform-soluble lipid was then determined. Lipid content was calculated on both a wet and dry weight basis. Dry weight of tissue was determined by heating to constant weight at $60^{\circ} \mathrm{C}$; ; pilot experiments showed that this procedure gave similar results to those obtained by heating at $100^{\circ}$ C. Control extractions with no tissue in the Soxhlet "thimble" were run and the values subtracted from the experimental results. Using the extraction procedure with small amounts (about $10 \mathrm{mg}$.) of olive oil, a 90 per cent. recovery was made.

(b) Histology.-Formal-calcium fixed frozen sections of blocks of tissue adjacent to that used for lipid extraction were prepared. The localization of lipid was demonstrated by coloration with Sudan black B. In costal cartilage an attempt was made to assess the amount of lipid contained in intra-cellular globules. In 100 cells in one section from each case, the numbers and diameters of lipid globules more than $1 \mu \mathrm{m}$. in diameter were counted. Fifty cells were in the central zone of the cartilage and another fifty in a rectangular area extending from the periphery of the cartilage to the outer limit of the central zone. Using data from cell-counts of these areas it was possible to calculate a value for the mean volume of lipid per cell. The assumption was made that all globules were spherical.

\section{Results}

(a) Lipid Extraction.-In costal cartilage, lipid content ranged from 0.28 to 1.47 per cent. wet weight. In articular cartilage, the values were similar, being from 0.32 to 3.48 per cent. wet weight.

(1) Changes with Age.-During the maturation period from birth to 30 years, the lipid content of costal cartilage fell from approximately 1.0 per cent to 0.4 per cent. wet weight. During the ageing 
period (31-89 years) lipid content increased from 0.4 to over 1.0 per cent. wet weight (Fig 1). On a dry weight basis, the values fell from 4.0 to 1.0 per cent. during the maturation period and rose from 1.0 to 3.0 per cent during ageing.

In articular cartilage there was no significant change with age either during the maturation or ageing period (Fig. 2). On a dry weight basis values ranged from 1.19 to 9.96 per cent.

(2) Sex Differences.-In costal cartilage the rate of increase of the lipid content during the period 31-89 years was almost identical in both sexes, although slightly less than that for the population as a whole (Fig. 3, opposite). However, at any given age, the lipid content was appreciably higher in the female than in the male. In contrast, in articular cartilage, there was no evidence for a difference between the sexes, mean values being for the male 1.05 per cent. and for the female $1 \cdot 11$ per cent.

(3) Effect of Nutritional State.-The post mortem specimens aged over 30 years at death were separated into two groups:

(i) Group A.-Those which had a history of loss of weight in the year preceeding death and in which abdominal subcutaneous fat was less than $5 \mathrm{~mm}$. thick.

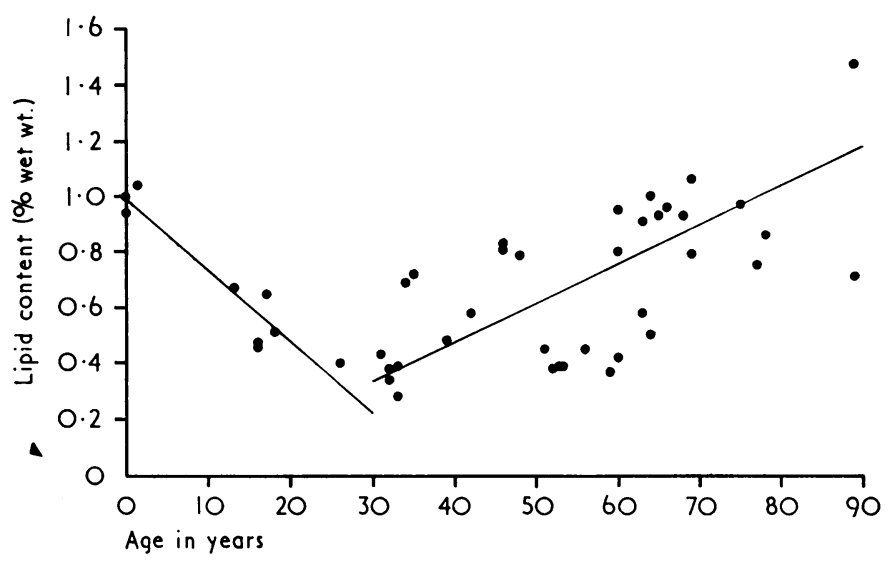

Fig. 1.-Lipid content of costal cartilage at various ages. Regression line data: (a) $0-30$ years: $y=0.99-0.026 x(t=8.0 ; \mathrm{P}<0.001)$
(b) $31-89$ years: $=-0.08+0.014 x(t=6.1 ; \mathrm{P}<0.001)$.

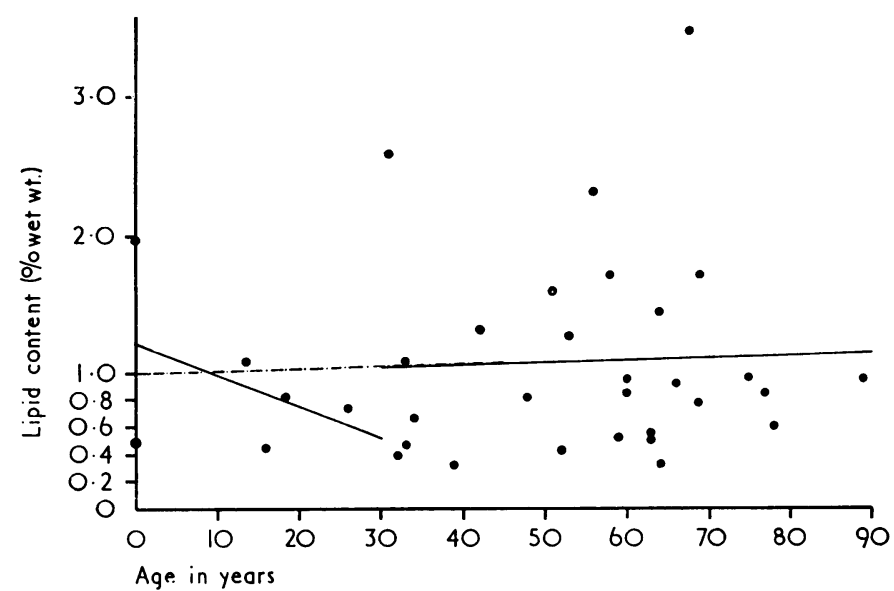

Fig. 2.- Lipid content of articular cartilage at various ages. There are no statistically significant changes during maturation, ageing, or the whole life-span (broken line). 


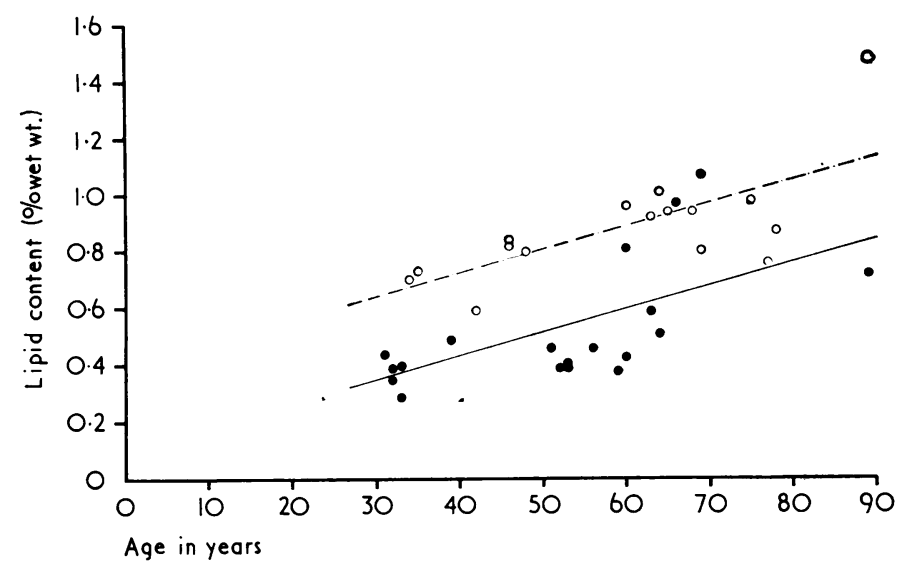

Fig. 3.-Sex difference in lipid content of costal cartilage.

(a) Male
(b) Female $0 \ldots-0.0$

The majority of these subjects had died from the effect of cancer.

(ii) Group B.-Those which had died either accidentally or without a long terminal illness and in which subcutaneous fat was $15 \mathrm{~mm}$. or more thick.

No conclusive evidence was obtained for a difference between these two groups in the lipid content of either costal or articular cartilage. However, in costal cartilage, the difference in the slope of the regression lines for the increase in lipid content during ageing was nearly significant at the 5 per cent level $(t=1.9 ; 0.1>\mathrm{P}>0.05$; Fig. 4). In articular cartilage, the mean value for Group $A$ (0.92 per cent.) was less than that for Group B ( $1 \cdot 11$ per cent.), but differences were not statistically significant. (b) Histology.-In costal cartilage, the mean volume of lipid per cell increased from almost nil to about $120 \mu \mathrm{m}^{3}$ (Fig. 5, overleaf) during the period from birth to 30 years. This peak value corresponds to an average lipid globule of about $5-6 \mu \mathrm{m}$. diameter in each cell. During ageing (31-89 years), this decreased to about one-fifth of the peak value. Despite a great deal of scatter in the results, the trends during maturation and ageing are clearly indicated.

There was no difference in the mean volume of the intracellular lipid globule between the two nutritional groups, nor was there a sex difference. Extracellular lipid was observed in costal cartilage from cadavers aged over 18 years. It was invariably observed in the territorial areas. It appeared to be more intense in the peripheral zone than in the central zone of the

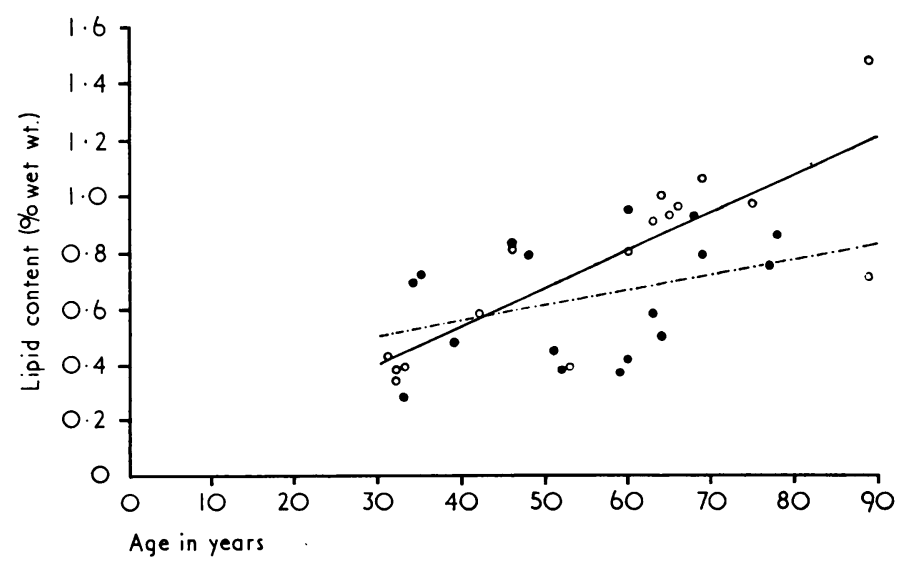

ig. 4. - Effect of nutritional state on lipid content of costal cartilage.

(a) Group A -.-.-0:y $y=0 \cdot 34+0 \cdot 0053 x$ (not significant.)

(b) Group B O-O: $y=0.0133 x(t=5 \cdot 7 ; \mathrm{P}<0.001)$. 


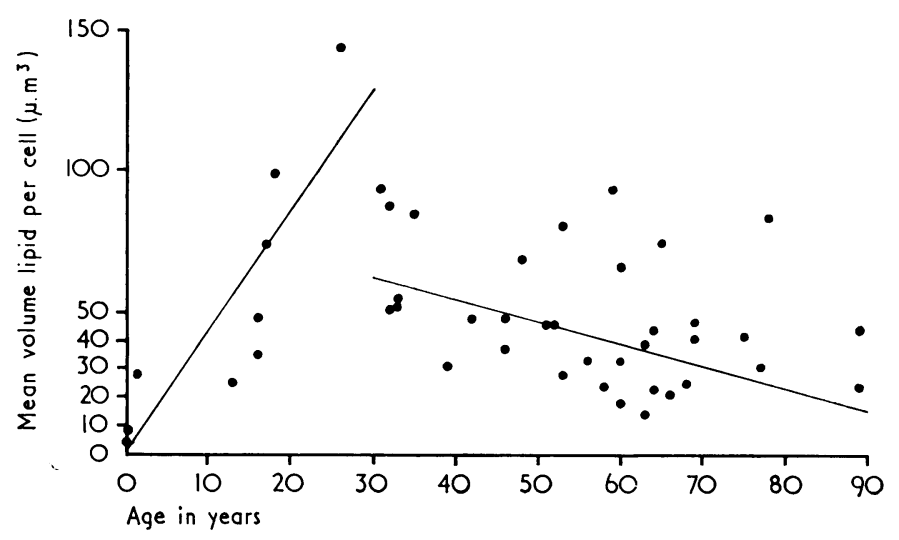

Fig. 5.-Mean volume of intracellular lipid (as Sudan black B-positive

globules) per cell in costal cartilage at various ages.
(a) $0-30$ years : $y=0 \cdot 4+4 \cdot 27 x(t=4 \cdot 4, \mathrm{P}<0 \cdot 005)$

(b) 31-89 years: $y=86 \cdot 2-0.68 x(t=2 \cdot 9, \mathrm{P}<0.01)$

cartilage. No consistent change in intensity was observed with ageing.

In articular cartilage, the upper middle zone cells contained the most lipid. This increased to a maximum at the end of the third decade. Extracellular lipid occurred $(a)$ around the cell capsule and (b) diffusely in the matrix of the superficial zone. Pericellular lipid was much less intense than in costal cartilage. It was more often observed in older specimens and around the cells of the middle zone of cartilage.

\section{Discussion}

The lipid content of articular and costal cartilage is similar, contributing about $0 \cdot 5-1 \cdot 0$ per cent. of the wet weight of most specimens. This is of the same order as that found by Hass (1943) in human costal cartilage using ether extraction. The present findings of age-correlated changes in the lipid content of costal cartilage, as compared with Hass' negative result, may be associated with the use of chloroform : methanol, which is a more efficient solvent than ether.

The changes found with maturation and ageing in the values for the mean volume of lipid per cell in costal cartilage are in agreement with the conclusions of Sacerdotti (1900). This author described an increase in the size of the lipid globule during maturation and a dimunition in later life in rabbit and in man. The results do not confirm the views of Wlassics (1930) and Bacsich and Wlassics (1931) that the maximal size of the intracellular lipid globule in hyaline and elastic cartilage is dependent on the grade of nutrition of the individual rather than age. (a) Changes in Lipid Content during Maturation.A decrease in extractable lipid occurs in both costal and articular cartilage, while both the size of the intracellular lipid globule and the amount of extracellular lipid become greater, particularly in costal cartilage. The apparent contradiction may be explained in terms of the changes which are occurring in the cell population. At birth most of the extract able lipid is in the form of structural lipid in celp membranes. Thus the seven-fold diminution incell-density taking place during maturation in cartilage (Stockwell, 1967) is a major factor involved in the fall in lipid content of the tissue. This offsets smaller absolute increases in the intracellular lipid globule and extra-cellular lipid.

(b) Changes during Ageing.-In costal cartilage the increase in extractable lipid is again at variance with the concomitant decline both in the mean volume of the intra-cellular lipid globule and also in the cell-density of the tissue (Stockwell, 1967). This suggests that the increase in lipid content of the tissue is largely due to an accumulation of extracellular lipid. The lack of histological evidence of such a process must be attributed to the difficulties of quantitating this rather diffuse form of lipid.

In articular cartilage no significant change occurs during ageing. Some increase in lipid content might be expected in view of the increasing incidence of diffuse extra-cellular lipid in the superficial zone during ageing (Stockwell, 1965; Ghadially and others, 1965).

It is possible that a small but real effect is being masked by the scatter in the results or that a change in the amount of lipid in the superficial zone is in- 
sufficient to alter the results of analyses of the full thickness of the tissue. However, it may be relevant that in normal mature articular cartilage there is also no detectable change with age in the water content (Linn and Sokoloff, 1965), cell density (Meachim and Collins, 1962; Stockwell, 1967), or mucopolysaccharide content (Anderson, Ludowieg, Harper, and Engleman, 1964; Bollet and Nance, 1966).

(c) Sex Difference in Costal Cartilage during Ageing.-The remarkable similarity in the rate of increase of lipid content in male and female tissue, coupled with a substantial difference in the actual content at any given age, suggests that the latter is due to factors operating in the maturation period. From measurements made of the radii of the transverse sections of costal cartilage used in this study, it may be calculated that the mean area of adult male sections is 40 per cent. higher than that of the female specimens (Stockwell, 1966). Hence, assuming that the two sexes are equal at birth with respect to dimensions and cell density in costal cartilage, it is suggested that the larger increment in growth in size of the male cartilage could result in a lower lipid content per unit weight of tissue compared with the female. Hence the female reaches adult life with a higher content than the male and the "differential" is maintained thereafter by process of accumulation of probably extracellular lipid.

(d) Effect of Nutritional Status.-The present results suggest some relationship between the nutritional status of the individual and the total amount of lipid in costal cartilage, although none with the amount of lipid in the form of intracellular globules. In the case of articular cartilage it is possible that a comparison of truly obese (rather than persons of normal physique) with thin individuals might yield more conclusive results. A proven connexion between obesity and lipid content of articular cartilage would be important in view of the higher incidence of osteo-arthritis in joints (including non-weight-bearing joints) of obese persons than in those of the normal (Kellgren and Lawrence, 1958).

\section{Summary}

Normal costal and articular cartilage was taken post mortem from cases of which the age at death ranged from 0 to 89 years. The total extractable lipid of the tissue was estimated and parallel histological studies made with frozen sections coloured with Sudan black B. In costal cartilage, lipid content decreases from 1.0 to 0.4 per cent. wet weight during the first three decades of life. Thereafter an increase occurs, until by the end of the eighth decade it exceeds 1.0 per cent. wet weight. The decrease in lipid content during maturation may be attributed to the concomitant reduction in cell-density of the tissue, despite the rapid increase in the mean volume of lipid per cell (in the form of Sudan black Bpositive globules) during this period. The increase in extractable lipid during ageing is probably associated with changes in the extracellular lipid of the tissue, for both cell-density and mean volume of lipid per cell decrease during later life. The lipid content of mature costal cartilage is greater in the female than in the male. There may also be a reduction in the amount of lipid in the cartilage of thin individuals. Neither sex nor nutritional status appears to affect the mean volume of lipid per cell.

Values for the lipid content of articular cartilage are of the same order as for that of costal cartilage. There are no changes with ageing, nor are there any sex differences in the lipid content of articular cartilage, and there is no evidence that the lipid content is influenced by the nutritional status of the individual.

I thank Prof. D. V. Davies for reading the text, and Dr. M. B. Thorn of the Department of Biochemistry for advice on methods of lipid extraction. I am grateful to the staff of the Department of Pathology for access to post mortem material, Messrs. A. L. Pache and V. C. Gregory for technical assistance, and Miss E. D. Joy for typing the manuscript.

\section{REFERENCES}

Anderson, C. E., Ludowieg, J., Harper, H. A., and Engleman, E. P. (1964). J. Bone Jt Surg., 46A, 1176 (The composition of the organic component of human articular cartilage).

Bacsich, P., and Wlassics, T. (1931). Z. mikrosk.-anat. Forsch., 24, 7 (Die Abhängigkeit des Fettgehaltes der Zellen des elastischen Knorpels vom Ernährungsgrad des Individuums).

Bollet, A. J., and Nance, J. L. (1966). J. clin. Invest., 45, 1170 (Biochemical findings in normal and osteo-arthritic articular cartilage. II. Chondroitin sulfate concentration and chain length, water, and ash content).

Collins, D. H., Ghadially, F. N., and Meachim, G. (1965). Ann. rheum. Dis., 24, 123 (Intracellular lipids of cartilage). 
Folch, J., Lees, M., and Sloane Stanley, G. H. (1957). J. biol. Chem., 226, 497 (A simple method for the isolation and purification of total lipides from animal tissues.)

Ghadially, F. N., Meachim, G., and Collins, D. H. (1965). Ann. rheum. Dis., 24, 136 (Extracellular lipid in the matrix of human articular cartilage.)

Hass, G. M. (1943). Arch. Path., 35, 375 (Studies of cartilage. IV. A morphologic and chemical analysis of aging human costal cartilage).

Kellgren, J. H., and Lawrence, J. S. (1958). Ann. rheum. Dis., 17, 388 (Osteo-arthrosis and disk degeneration in an urban population).

Linn, F. C., and Sokoloff, L (1965) Arthr. and Rheum., 8, 481 (Movement and composition of interstitial fluid of cartilage).

Meachim, G., and Collins, D. G. (1962). Ann. rheum. Dis., 21, 45 (Cell counts of normal and osteoarthritic articular cartilage in relation to the uptake of sulphate $\left({ }^{35} \mathrm{SO}_{4}\right)$ in vitro $)$.

Putschar, W. (1931). Beitr. path. Anat., 87, 526 (Über Fett im Knorpel unter normalen und pathologischen Verhältnissen).

Sacerdotti, C. (1900). Virchows Arch. path. Anat. Physiol., 159, 152 (Ueber das Knorpelfett).

Stockwell, R. A. (1965). Nature (Lond.), 207, 427 (Lipid in the matrix of ageing articular cartilage). (1966). Ph.D Thesis. University of London. (The ageing of cartilage).

- (1967). J. Anat., in press. (The cell-density of human articular and costal cartilage).

Wlassics, T. (1930). Z. mikrosk.-anat. Forsch., 22, 220 (Über den Zusammenhang der Änderung des Fettgehaltes der Zellen des hyalinen Knorpels mit dem Ernährungsgrad des Individuums).

Zbinden, G. (1953). Schweiz Z. allg. Path. Bakt., 16, 165 (Uber Feinstruktur und Altersveränderungen des hyalinen Knorpels im elektronen-mikroskopischen Schnittpräparat und Beitrag zur Kenntnis der Verfettung der Knorpelgrundsubstanz).

La teneur en lipides du cartilage costal et articulaire chez l'homme

\section{RÉSUMÉ}

On préleva le cartilage costal et articulaire sur des cadavres dont l'âge, au moment du décès, allait de 0 à 89 ans. On détermina la totalité de lipides extractibles des tissus et on procéda en même temps à l'étude histologique sur des coupes congelées colorées au noir Soudan B. Dans le cartilage costal la teneur en lipides diminue de 1,0 à 0,4 pour cent du poids (sans dessécher) pendant les trois premières décades de la vie. Après cela il y a une augmentation et à la fin de la huitième décade le poids dépasse 1,0. La chûte de la teneur en lipides pendant le développement peut être imputée à la réduction concomitante de la densité cellulaire du tissu, malgré l'accroissement rapide du volume moyen des lipides dans la cellule (sous forme de globules prenant le noir Soudan B) pendant cette période. L'augmentation du taux des lipides extractibles au cours du vieillissement est probablement associée aux altérations des lipides extracellulaires du tissu, car tant la densité cellulaire que le volume moyen des lipides par cellule tendent à diminuer à un âge plus avancé. La teneur en lipides du cartilage costal mâture est plus grande chez la femme que chez l'homme. Il peut y avoir aussi une diminution de la quantité de lipides du cartilage chez les sujets maigres. Ni le sexe ni le facteur alimentaire ne paraissent affecter le volume moyen des lipides cellulaires.

Le taux des lipides est le même dans le cartilage articulaire et dans le cartilage costal. En ce qui concerne la teneur en lipides du cartilage articulaire, l'âge et le sexe ne jouent aucun rôle et rien n'indique que l'alimentation de l'individu ait une influence quelconque sur elle.
El contenido lípido del cartílago costal y articular humanoe SUMARIO

Se recogió el cartílago costal y articular de cadávers cuya edad, al tiempo de la muerte, se extendía de 0 a 89 años. Se determinó la totalidad de los lípidos que se pudo extraer de los tejidos y se hizo al mismo tiempo un estudio histológico sobre cortes helados y colorados con el negro Sudan B. En el cartílago costal el contenido lípido baja de un 1,0 a 0,4 por ciento del peso (húmedo) durante las tres primeras décadas de la vida. Luego el peso tiende a subir para alcanzar el 1,0 por ciento a los ochenta años. La caída del contenido lípido en la época del desarrollo pude atribuirse a la reducción concomitante de la densidad celular del tejido, a pesar del acrecimiento rápido del volumen medio de los lípidos celulares (en forma de glóbulos colorados por el negro Sudan B) durante esta época. El aumento de los lípidos que se pueden extraer en la época de envejecimiento se ve probablemente asociado con alteraciones de los lípidos extracelulares del tejido, ya que la densidad celular y el volumen medio de los lípidos celulares tienden a disminuir con la edad avanzada. Las cifras de los lípidos del cartílago costal maduro son mayores en la mujer que en el hombre. Se puede observar también una reducción de los lípidos en el cartílago de sujetos delgados. Ni el sexo, ni el factor alimenticio parecen afectar el volumen medio de los lípidos celulares.

Las cifras de los lípidos en el cartílago articular se parecen a las en el cartílago costal. El contenido lípido del cartilago articular no se ve afectado por la edad o por el sexo; tampoco hay pruebas de que el estado alimenticio del sujeto tenga importancia alguna. 